\title{
PENGARUH NEEDS FOR ACHIEVEMENT DAN KARAKTERISTIK PRIBADI TERHADAP KEINGINAN BERWIRAUSAHA: STUDI PADA MAHASISWA FE UNTAR
}

\author{
Fanny Andriani Setiawan \& Herni Kurniawati \\ Fakultas Ekonomi Universitas Tarumanagara \\ Email:fanny.andriani@yahoo.com
}

\begin{abstract}
The purpose of this study was to analyze Effect Needs for Achievement and Personal Characteristics Of Desire Entrepreneurship: Studies in FE Student UNTAR. The data used in this study is primary data obtained from a questionnaire research instruments were given to FE students UNTAR. Of the 500 questionnaires distributed, the number of questionnaires returned and deserves to dioleha of 420 questionnaires. Data using multiple regression analysis to answer the hypothesis peneilitian with the software PASW Statistics 18 and Eviews 6. This research was carried Faculty of Economics, University of Tarumanagara, with the object of study is a student. This study uses survey research with primary data collection using questionnaires. The selection of samples tested in this study using purposive sampling method, 420 respondents was selected as the study sample. The results of this study were (1) Needs for achievement has a positive effect on the willingness of students to entrepreneurship, (2) Gender positive effect on the willingness of students to entrepreneurship, (3) Age does not affect the desire of students to entrepreneurship, and (4) work experience possessed FE students UNTAR not affect students for entrepreneurship.
\end{abstract}

Keywords: Needs for achievement, gender, age, work experience, the desire of students to entrepreneurship

Abstrak: Tujuan dari penelitian ini adalah untuk menganalisis Pengaruh Needs for Achievement dan Karakteristik Pribadi Terhadap Keinginan Berwirausaha: Studi pada Mahasiswa FE UNTAR. Data yang digunakan di penelitian ini merupakan data primer yang diperoleh dari instrumen penelitian berupa kuesioner yang diberikan kepada mahasiswa FE UNTAR. Dari 500 kuesioner yang disebarkan, jumlah kuesioner yang kembali dan layak untuk dioleha sebesar 420 kuesioner. Analisis data menggunakan regresi berganda untuk menjawab hipotesis peneilitian dengan software PASW Statistic 18 dan Eviews 6. Penelitian ini dilaksanakan Fakultas Ekonomi Universitas Tarumanagara, dengan objek penelitian adalah mahasiswa. Penelitian ini menggunakan metode penelitian survei dengan pengumpulan data primer yang menggunakan kuesioner. Pemilihan sampel yang diuji dalam penelitian ini menggunakan metode purposive sampling, terpilih 420 responden sebagai sampel penelitian. Hasil dari penelitian ini adalah (1) Needs for achievement berpengaruh positif terhadap keinginan mahasiswa untuk berwirausaha, (2) Jender berpengaruh positif terhadap keinginan mahasiswa untuk berwirausaha, (3) Umur tidak mempengaruhi keinginan mahasiswa untuk berwirausaha, dan (4) Pengalaman kerja yang dimiliki mahasiswa FE UNTAR tidak mempengaruhi mahasiswa untuk berwirausaha.

Kata kunci: Needs for achievement, jender, umur, pengalaman kerja, keinginan mahasiswa untuk berwirausaha 


\section{PENDAḦULUAN}

Peran wirausaha sangat penting dan menentukan masa depan bangsa dan negara. Secara umum, wirausaha sangat diperlukan untuk memperkuat perekonomian Indonesia. Pembangunan Indonesia akan lebih mantap bila ditunjang oleh adanya para wirausahawan yang ulet dan tangguh, karena kemampuan pemerintah sangat terbatas dalam penyediaan lapangan kerja baru (Dikti, 2009). Aktivitas kewirausahaan (entrepreneurial activity) di Indonesia dewasa ini masih rendah. Salah satu penyebab rendahnya aktivitas kewirausahaan adalah lulusan perguruan tinggi yang notabene mempunyai kemampuan dan keilmuan yang lebih tinggi, masih lebih banyak yang berperan sebagai pencari kerja dari pada sebagai pencipta lapangan kerja. Hal ini mungkin disebabkan oleh karena sistem pembelajaran yang diterapkan di berbagai perguruan tinggi di Indonesia lebih terfokus pada bagaimana menyiapkan para mahasiswa yang cepat lulus dan mendapat pekerjaan dari pada menciptakan lulusan yang siap menciptakan lapangan kerja.

Penelitian ini bertujuan untuk menganalisis Pengaruh Needs for Achievement dan Karakteristik Pribadi Terhadap Keinginan Berwirausaha mahasiswa FE UNTAR. Penelitian ini juga diharapkan dapat memberikan informasi yang dibutuhkan dan bermanfäat bagi pengajar FE UNTAR agar dapat menumbuhkan minat berwirausaha.

Kewirausahaan. Kewirausahaan adalah suatu proses kreativitas dan inovasi yang mempunyai resiko tinggi untuk menghasilkan nilai tambah bagi produk yang bermanfaat bagi masyarakat dan mendatangkan kemakmuran bagi wirausahawan. Kewirausahaan itu dapat dipelajari walaupun ada juga orang-orang tertentu yang mempunyai bakat dalam hal kewirausahaan.

Inovasi adalah Kunci Penting Kewirausahaan. Wirausahawan revolusi Industri Inggris menunjukkan kunci penting dalam membangun kepribadian-semangat inovasi. Mereka terlibat dalam pengembangan penemuan untuk tujuan komersil dan menerapkan penemuan ilmiah untuk tujuan produksi. Keberhasilan mereka membuktikan adanya nilai dari pengerjaan sesuatu yang baru dan berguna atau mengerjakan sesuatu yang lama dengan era baru dan lebih baik. Di dalam usahanya, mereka menetapkan suatu nilai dasar yang harus diikuti oleh para wirausahawan-bahwa inovasi harus merupakan karakteristik utama dari usaha-usaha kewirausahaan. Kreatifitas adalah hakikat dari tindakan-tindakan kewirausahaan (Hisrich dan Peters, 2002).

Telaah Literatur dan Hipotesis. McClelland $(1961,1971)$ memperkenalkan konsep kebutuhan akan prestasi sebagai salah satu motif psikologis. Kebutuhan akan prestasi dapat diartikan sebagai suatu kesatuan watak yang memotivasi seseorang untuk menghadapi tantangan untuk mencapai kesuksesan dan keunggulan (Lee, 1997). Lebih lanjut, McClelland (1971) menegaskan bahwa kebutuhan akan prestasi sebagai salah satu karakteristik kepribadian seseorang yang akan mendorong seseorang untuk memiliki keinginan kewirausahaan. Hasil penelitian dari Scapinello (1989) dan Sengupta dan Debnath (1994) mengungkapkan bahwa kebutuhan akan prestasi berpengaruh pada atribut kesuksesan dan kegagalan berwirausaha. Lebih spesifik, kebutuhan akan prestasi juga dapat mendorong kemampuan pengambilan keputusan dan kecenderungan untuk mengambil risiko seorang wirausaha. Semakin tinggi kebutuhan akan prestasi seorang wirausaha, semakin banyak keputusan tepat yang akan diambil. Wirausaha dengan kebutuhan akan prestasi tinggi adalah pengambil risiko yang moderat dan menyukai hal- 
hal yang menyediakan balikan yang tepat dan cepat. Berdasarkan uraian tersebut, maka hipotesis dirumuskan sebagai berikut:

H1 Needs for achievement berpengaruh positif terhadap keinginan berwirausaha.

Pengaruh jender atau jenis kelamin terhadap intensi seseorang menjadi wirausaha telah banyak diteliti (Mazzarol et al., 1999; Kolvereid, 1996; Matthews dan Moser, 1996; Schiller dan Crewson, 1997). Seperti yang sudah diduga, bahwa mahasiswa laki-laki memiliki keinginan yang lebih kuat dibandingkan mahasiswa perempuan. Secara umum, sektor wiraswasta adalah sektor yang didominasi oleh kaum laki-laki. Mazzarol et al., (1999) membuktikan bahwa perempuan cenderung kurang menyukai untuk membuka usaha baru dibandingkan kaum laki-laki. Temuan serupa juga disampaikan oleh Kolvereid (1996), laki-laki terbukti mempunyai keinginan kewirausahaan yang lebih tinggi dibandingkan perempuan. Penelitian yang dilakukan oleh Matthews dan Moser (1996) pada lulusan master di Amerika dengan menggunakan studi longitudinal menemukan bahwa minat laki-laki untuk berwirausaha konsisten dibandingkan minat perempuan yang berubah menurut waktu. Schiller dan Crawson (1997) menemukan adanya perbedaan yang signifikan dalam hal kesuksesan usaha dan kesuksesan dalam berwirausaha antara perempuan dan laki-laki. Berdasarkan uraian tersebut, hipotesis yang akan dijawab dalam penelitian ini dirumuskan:

H2 Jender berpengaruh positif terhadap keinginan berwirausaha. Laki-laki mempunyai keinginan kewirausahaan lebih tinggi daripada wanita.

Hasil penelitian yang dilakukan oleh Sinha (1996) di India, menunjukkan bahwa hampir sebagian besar wirausaha yang sukses adalah mereka yang berusia relatif muda. Hal ini senada dengan Reynolds et al., (2000) yang menyatakan bahwa seseorang berusia 25-44 tahun adalah usia-usia paling aktif untuk berwirausaha di negara-negara barat. Hasil penelitian terbaru terhadap wirausaha warnet di Indonesia membuktikan bahwa usia wirausaha berkorelasi signifikan terhadap kesuksesan usaha yang dijalankan (Kristiansen et al., 2003). Senada dengan hal itu, Dalton dan Holloway (1989) membuktikan bahwa banyak calon wirausaha yang telah mendapat tanggung jawab besar pada saat berusia muda, bahkan layaknya seperti menjalankan usaha baru. Oleh karena itu, rumusan hipotesis yang akan diteliti adalah:

H3 Umur berpengaruh positif terhadap keinginan berwirausaha. Mahasiswa yang berusia muda memiliki keinginan kewirausahaan yang lebih tinggi dibandingkan mereka yang berusia tua.

Kolvereid (1996) menemukan bahwa seseorang yang memiliki pengalaman bekerja mempunyai keinginan kewirausahaan yang lebih tinggi dibandingkan mereka yang tidak pernah bekerja sebelumnya. Sebaliknya, secara lebih spesifik, penelitian yang dilakukan oleh Mazzarol et al., (1999) membuktikan bahwa seseorang yang pernah bekerja di sektor pemerintahan cenderung kurang sukses untuk memulai usaha. Nàmun, Mazzarol et al., (1999) tidak menganalisis hubungan antara pengalaman kerja di sektor swasta terhadap keinginan kewirausahaan. Scott dan Twomey (1988) meneliti beberapa faktor seperti pengaruh orang tua dan pengalaman kerja yang akan mempengaruhi persepsi seseorang terhadap suatu usaha dan sikap orang tersebut terhadap keinginannya untuk menjadi karyawan atau wirausaha. Lebih lanjut, mereka menyebutkan bahwa jika kondisi lingkungan sosial seseorang pada saat dia berusia muda kondusif untuk kewirausahaan dan seseorang tersebut memiliki pengalaman yang positif terhadap sebuah usaha, maka dapat dipastikan orang tersebut mempunyai gambaran yang baik tentang kewirausahaan. Dengan demikian, maka dapat dikemukakan hipotesis sebagai berikut: 
H4 Pengalaman kerja berpengaruh positif kepada keinginan berwirausaha. Mahasiswa yang memiliki pengalaman kerja memiliki keinginan kewirausahaan yang lebih tinggi dibandingkan dengan mereka yang belum pernah bekerja sebelumnya

Kerangka Penelitian. Adapun kerangka penelitian dalam penelitian ini adalah :

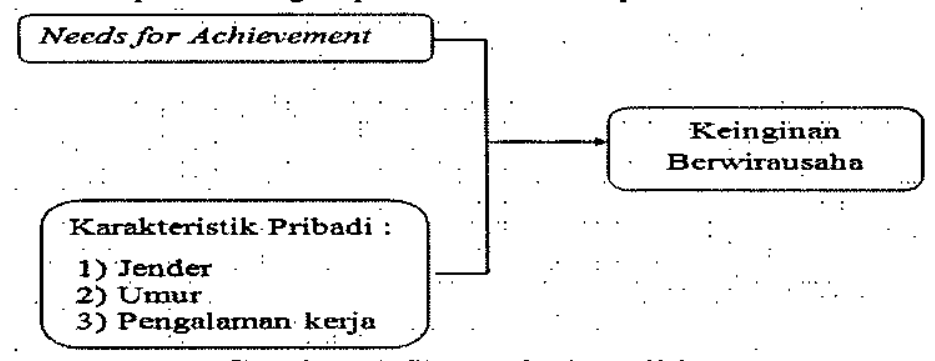

Gambar 1. Kerangka Penelitian

Tujuan dari penelitian ini adalah untuk: (a) Mengetahui pengaruh Needs for achievement terhadap keinginan mahasiswa FE Universitas Tarumanagara berwirausaha.; (b) Mengetahui pengaruh jender terhadap keinginan mahasiswa FE Universitas Tarumanagara berwirausaha.; (c) Mengetahui pengaruh umur terhadap keinginan mahasiswa FE Universitas Tarumanagara berwirausaha.; (d) Mengetahui pengaruh pengalaman kerja terhadap keinginan mahasiswa FE Universitas Tarumanagara berwirausaha.

Adapun manfaat penelitian ini adala sebagai berikut: (a) Bagi perguruan tinggi; hasil penelitian ini dapat menjadi masukan dalam merancang kebijakan dalam rangka menghasilkan entrepreneurs. Perguruan tinggi dapat merancang kurikulum yang dapat membentuk dan memperkuat sikap dan perilaku kewirausahaan mahasiswa.; (b) Bagi mahasiswa; menyadari pentingnya kewirausahaan sehingga setelah lulus mahasiswa dapat terlibat dalam kewirausahaan.; (c) Bagi pemerintah; hasil penelitian ini dapat menjadi masukan untuk menghasilkan peraturan maupun kebijakan yang mendorong perguruan tinggi dan mahasiswa untuk menjalankan dan menyukseskan program kewirausahaan di Indonesia umumnya.; (d) Bagi ilmu pengetahuan; hasil penelitian ini menambah body of knowledge dan memperkaya literatur mengenai faktor-faktor yang berpengaruh kepada keinginan berwirausaha.

\section{METODE}

Sampel. Populasi penelitian ini adalah mahasiswa S1 Fakultas Ekonomi Universitas Tarumanagara. Sampel diambil sebanyak 500 (lima ratus) mahasiswa yang terdiri dari jurusan Akuntansi dan Manajemen yang kuliahnya tersebar di beberapa angkatan. Pengambilan sampel didasarkan pada judgement atau purposive sampling, yaitu sampel dipilih dengan adanya beberapa kriteria tertentu yang digunakan oleh peneliti (Remenyi, 2000). Adapun kriteria sampel penelitian yang digunakan adalah mahasiswa aktif (tidak dalam kondisi cuti kuliah) dalam perkuliahan.

Data dan Teknik Pengumpulan Data. Data penelitian ini adalah data primer yang dikumpulkan melalui kuesioner. Kuesioner penelitian didistribusikan secara langsung dengan tujuan untuk mendapatkan tingkat pengembalian yang tinggi. Pengumpulan data dilakukan didalam kampus seperti kantin, tempat bersantai, dan gedung perkuliahan. 
Variabel Independen (X). Needs for achievement dapat diartikan sebagai suatu kesatuan watak yang memotivasi seseorang untuk menghadapi tantangan untuk mencapai kesuksesan dan keunggulan (Lee, 1997). Lebih lanjut, McClelland dalam Indarti dan Rostiani (2008) menegaskan bahwa kebutuhan akan prestasi sebagai salah satu karakteristik kepribadian seseorang yang akan mendorong seseorang untuk memiliki keinginan berwirausaha. Menurut Indarti dan Rostiani (2008), ada tiga indikator yang melekat pada seseorang yang mempunyai kebutuhan akan prestasi yang tinggi (Needs for achievement) yaitu: (1) Menyukai tanggung jawab pribadi dalam mengambil keputusan; (2) Mau mengambil resiko sesuai dengan kemampuannya; dan (3) Memiliki minat untuk selalu belajar dari keputusan yang telah diambil.

Variabel Needs for achievement menggunakan instrumen penelitian yang terdiri dari tujuh item pernyataan yang diukur dengan skala likert lima poin. Dari tujuh item pernyataan terdapat satu buah pernyataan negatif bertujuan untuk melihat konsistensi mahasiswa untuk menjawab kuesioner secara sungguh-sungguh. Nilai lima diberikan untuk responden yang menyatakan sikap "sangat setuju" bagi mahasiswa yang memiliki kebutuhan berprestasi untuk berwiraswasta. Nilai satu diberikan untuk responden yang menyatakan sikap "sangat tidak setuju" bagi mahasiswa yang tidak memiliki kebutuhan berprestasi untuk berwiraswasta.

Variabel independen lain dalam penelitian ini yang mendorong keinginan mahasiswa untuk berwirausaha adalah karakteristik pribadi yang diwakili dengan jender, pengalaman kerja, dan umur mahasiswa. Variabel jender merupakan variabel dummy dengan nilai 1 untuk mahasiswa laki-laki dan 0 untuk mahasiswa perempuan. Alasan mahasiswa laki-laki diberi nilai 1 adalah dikarenakan mahasiswa laki-laki memiliki keinginan yang lebih kuat dibandingkan dengan mahasiswa perempuan.

Variabel karakteristik pribadi selanjutnya adalah pengalaman kerja yang merupakan variabel dummy dengan nilai 1 untuk mahasiswa yang memiliki pengalaman kerja dan 0 untuk lainnya. Menurut Kolvereid (1996) menemukan bahwa seseorang yang memiliki pengalaman bekerja mempunyai keinginan kewirausahaan yang lebih tinggi dibandingkan mereka yang tidak pernah bekerja sebelumnya. Variabel terakhir yang membentuk karakteristik pribadi dalam penelitian ini adalah umur mahasiswa yang diukur dengan angka.

Variabel Dependen (Y). Keinginan berwirausaha menurut Agustina dan Sularto (2011) dapat diartikan sebagai proses pencarian informasi yang dapat digunakan untuk mencapai tujuan pembentukan suatu usaha. Seseorang dengan intensi untuk memulai usaha akan memiliki kesiapan dan kemajuan yang lebih baik dalam usaha yang dijalankan dibandingkan seseorang tanpa intensi untuk memulai usaha (Agustina dan Sularto, 2011). Menurut Indarti dan Rostiani (2008) indikator yang melekat pada keinginan berwirausaha adalah: (1) Tekad yang kuat untuk memilih karir menjadi seorang wirausaha; dan (2) Keyakinan akan adanya peluang untuk berhasil menjadi seorang wirausaha.

Variabel Keinginan berwirausaha menggunakan instrumen penelitian yang terdiri dari 5 (lima) item pernyataan yang diukur dengan skala likert 5 (lima) poin. Dari 5 (lima) item pernyataan terdapat satu buah pernyataan negatif bertujuan untuk melihat konsistensi mahasiswa untuk menjawab kuesioner secara sungguh-sungguh. Nilai 5 (lima) diberikan untuk sikap responden yang menyatakan sikap "sangat setuju" bagi mahasiswa yang memiliki minat untuk berwiraswasta setelah lulus kuliah. Nilai 1 (satu) diberikan untuk sikap responden yang menyatakan sikap "sangat tidak setuju" bagi mahasiswa yang tidak memiliki minat untuk berwiraswasta setelah lulus kuliah. 
Tabel 1. Operasionalisasi Variabel

\begin{tabular}{lcllc}
\hline \multicolumn{1}{c}{ Variabel } & Jenis Variabel & \multicolumn{1}{c}{ Indikator } & Skala \\
\hline Needs for achievement & Independen & 1) & $\begin{array}{l}\text { Menyukai tanggung jawab } \\
\text { pribadi dalam mengambil } \\
\text { keputusan }\end{array}$ & Ordinal \\
Sumber: & & 2) & $\begin{array}{l}\text { Mau mengambil resiko sesuai } \\
\text { dengan kemampuannya }\end{array}$ & \\
$\begin{array}{l}\text { McCleland (1971) dalam } \\
\text { Indarti dan Rostiani (2008) }\end{array}$ & 3) & $\begin{array}{l}\text { Memiliki minat untuk selalu } \\
\text { belajar dari keputusan yang telah } \\
\text { diambil }\end{array}$ & \\
& & 1) & $\begin{array}{l}\text { Tekad yang kuat untuk memilih } \\
\text { karir menjadi seorang wirausaha }\end{array}$ & Ordinal \\
Keinginan berwirausaha & Dependen & 2) & $\begin{array}{l}\text { Keyakinan akan adanya peluang } \\
\text { untuk berhasil menjadi seorang } \\
\text { wirausaha }\end{array}$ & \\
Sumber: & & &
\end{tabular}

Metode Analisis. Penelitian ini menggunakan regresi berganda untuk menjawab hipotesis penelitian. Adapun persamaan regresi penelitian ini adalah sebagai berikut:

Dengan definisi variabel sebagai berikut:

$$
Y=a+b_{1} \cdot x_{1}+b_{2} \cdot D_{1}+b_{3} \cdot x_{2}+b_{4} \cdot D_{2}+\varepsilon
$$

Variabel Dependen

$\mathrm{Y} \quad=$ Keinginan berwirausaha

Variabel Independen

$a=$ Konstanta

$\mathrm{X}_{1} \quad=\quad$ Needs for achievement

$\mathrm{D}_{1} \quad=$ Dummi jender, dengan nilai 1 untuk mahasiswa laki-laki dan 0 untuk mahasiswa perempuan.

Pemberian nilai 1 untuk mahasiswa laki-laki dikarenakan mahasiswa lakilaki memiliki keinginan yang lebih kuat dibandingkan dengan mahasiswa perempuan. Secara umum, sektor wiraswasta adalah sektor yang didominasi oleh kaum laki-laki. Mazzarol et al. (1999) membuktikan bahwa perempuan cenderung kurang menyukai untuk membuka usaha baru dibandingkan kaum laki-laki.

$\mathrm{X}_{2} \quad=$ Umur

$\mathrm{D}_{2}=$ Dummi pengalaman kerja, dengan nilai 1 untuk mahasiswa yang memiliki pengalaman kerja dan 0 untuk lainnya.

Menurut Kolvereid (1996) menemukan bahwa seseorang yang memiliki pengalaman bekerja mempunyai keinginan kewirausahaan yang lebih tinggi dibandingkan mereka yang tidak pernah bekerja sebelumnya. Penelitian ini juga didukung oleh Indarti dan Rostiani (2008).

Koefisien variabel bebas

$b_{1}-b_{4} \quad$ Tingkat kesalahan estimasi

$\varepsilon$

Uji Validitas dan Reliabilitas. Uji Validitas. Instrumen dikatakan valid apabila mampu mengukur apa yang diinginkan dan dapat mengungkap data variabel yang diteliti secara tepat. Dalam survei uji validitas dilakukan dengan mengkorelasikan skor setiap item 
dengan total skor. Teknik korelasi yang digunakan adalah Pearson Product Moment, dimana instrumen dikatakan valid apabila nilai koefisien korelasinya $(r)>r$ tabel.

Uji Reliabilitas. Sugiyono (2008), berpendapat bahwa instrumen dikatakan reliabel adalah instrumen yang jika digunakan beberapa kali dalam waktu yang berbeda untuk mengukur obyek yang sama akan menghasilkan data yang sama. Dalam penelitian ini uji reliabilitas digunakan Tehnik Alpha Cronbach, dimana suatu instrumen dapat dikatakan reliabel apabila memiliki koefisien keandalan (alpha) > 0,6 (Ghozali, 2005).

Uji Asumsi Klasik. Uji Normalitas. Model regresi yang baik adalah memiliki distribusi data normal atau mendekati normal (Ghozali, 2005). Untuk mengetahui apakah data berdistribusi normal atau tidak pada penelitian ini digunakan uji Kolmogorov-Smirnov. Dalam uji Kolmogorov-Smirnov (uji K-S), hipotesis nol yang diajukan adalah data tidak berdistribusi normal. Sedangkan hipotesis alternatif nya adalah data berdistribusi normal. Dengan demikian jika hasil uji K-S menunjukkan angka yang signifikan, berarti data yang diuji adalah berdistruibusi tidak normal. Sebaliknya, jika hasil uji K-S tidak signifikan, berarti data berdistribusi normal.

Uji Multikolinieritas. Uji multikolinieritas untuk menguji apakah model regresi mempunyai korelasi antar variabel bebas. Model regresi yang baik adalah tidak terjadi korelasi di antara variabel bebasnya (Winarno, 2009). Model regresi dikatakan tidak terdapat multikolinieritas apabila mempunyai nilai VIF $<10$ dan mempunyai nilai Tolerance $>0,1$.

Uji Heteroskedastisitas. Digunakan untuk menguji apakah dalam model regresi terjadi kesamaan varians dari residual satu pengamatan ke pengamatan lainnya. Model regresi yang baik adalah yang homoskedastisitas (Winarno, 2009). Penelitian ini menggunakan uji Park, merupakan salah satu metode dari tujuh metode, untuk menguji ada tidaknya masalah heteroskedastisitas. Model regresi dikatakan tidak bersifat heteroskedastisitas apabila probabilitas dari masing-masing variabel independennya (bebas) tidak signifikan (p-value $>5 \%$ ).

Pengujian Hipotesis. Untuk melakukan keputusan menerima atau menolak hipotesis yang diajukan, maka perlu dilakukan pengujian secara statistik dengan menggunakan regresi linier sederhana dan berganda yang bertujuan untuk mengetahui Needs for Achievement dan Karakteristik Pribadi yang dijelaskan dengan variabel umur, pengalaman bekerja, dan jender terhadap Keinginan Berwirausaha, yang diolah dengan program komputer Eviews 6 atau PASW Statistic 18. Pengujian hipotesis untuk melihat pengaruh variabel independen terhadap variabel dependen secara parsial digunakan uji $t$. Jika $t_{\text {hitung }}>\mathrm{t}_{\text {tabel }}$ dengan tingkat signifikan $5 \%$, maka dapat disimpulkan bahwa secara parsial variabel independen berpengaruh signifikan terhadap variabel dependen. Jika $t_{\text {hitung }}<t_{\text {tabel }}$ dengan tingkat signifikan $5 \%$, maka dapat disimpulkan bahwa variabel independen tidak berpengaruh terhadap variabel dependen.

\section{HASIL DAN PEMBAHASAN}

Analisis Karakteristik Responden. Analisis karateristik responden menunjukkan jumlah data yang diolah berasal dari kuesioner yang kembali dan dapat digunakan. Dalam hal ini, kuesioner yang tidak layak akan dibuang dan tidak dimasukkan dalam pengolahan data. 
Setiawan \& Kurniawati: Pengaruh Needs For Achievement Dan Karakteristik Pribadi...

Kuesioner yang tidak layak merupakan kuesioner yang tidak lengkap. Selengkapnya dapat dilihat pada tabel berikut.

Tabel 2. Penyebaran Kuesioner Mahasiswa FE UNTAR

\begin{tabular}{cccccc}
\hline No. & Status Kuliah & Sebar & Kembali & Tidak Layak & Final \\
\hline Mahasiswa Aktif & 500 & 457 & 37 & 420 \\
\hline
\end{tabular}

Sumber: Data olahan 2013

Berdasarkan tabel di atas, dapat disimpulkan persentase jumlah kuesioner yang kembali dan layak digunakan dalam penelitian ini adalah sebesar $84 \%$.

Berdasarkan total dari data pengembalian kuesioner tersebut, dapat diketahui karakteristik dari responden. Dalam penelitian ini, karakteristik responden digolongkan berdasarkan jenis kelamin, usia, status kuliah, dan perrnah mengambil cuti atau tidak. Keterangan mengenai karakteristik responden dapat dilihat pada tabel 3.

Tabel 3. Karakteristik Responden

\begin{tabular}{lccc}
\hline \multicolumn{1}{c}{ Karakteristik Responden } & Kategori & Jumlah & Persentase (\%) \\
\hline Jensi Kelamin & Laki-laki & 155 & 37 \\
& Perempuan & 265 & 63 \\
Usia & Total & 420 & 100 \\
& $\leq 20$ tahun & 236 & 56,19 \\
\multirow{4}{*}{ Pengalaman bekerja } & $>20$ tahun & 184 & 43,81 \\
& Total & 420 & 100 \\
\multirow{3}{*}{ Jurusan } & Memiliki & 103 & 24,52 \\
& Tidak Memiliki & 317 & 75,48 \\
& Total & 420 & 100 \\
& Akuntansi & 343 & 81,67 \\
& Manajemen & 77 & 18,33 \\
\hline
\end{tabular}

Sumber: Data Olahan 2013

Hasil Uji Validitas. Pada pengujian validitas, dilakukan dengan mengkorelasikan skor setiap ítem pernyataan dengan total skor. Teknik korelasi yang digunakan adalah Pearson Product Moment, dimana instrumen dikatakan valid apabila nilai koefisien korelasinya (r) $>\mathrm{r}$ tabel.

Hasil Uji Validitas Needs for Achievement. Instrumen pengukuran Needs for Achievement yang akan digunakan dalam penelitian ini mengacu pada instrumen pengukuran yang digunakan oleh McCleland (1971) dalam Indarti dan Rostiani (2008), yang mengelompokkan Needsss for Achievement menjadi tiga indikator yaitu menyukai tanggung jawab pribadi dalam mengambil keputusan, mau mengambil resiko sesuai dengan kemampuannya, dan memiliki minat untuk selalu belajar dari keputusan yang telah diambil. Pengukuran variabel Needs for Achievement dalam penelitian ini menggunakan tujuh item pernyataan untuk ketiga indikator termasuk satu item pernyataan negatif, dimana ketujuh item pernyataan tersebut dilakukan terlebih dahulu pretest kepada 50 responden. Hasil dari pretest tersebut menghasilkan enam item pernyataan yang valid dan satu item pernyataan tidak valid (pernyataan negatif), sehingga harus di hilangkan. Adapun hasil item pernyataan yang valid terlampir dalam Tabel berikut ini. 
Tabel 4. Hasil Pengujian Validitas Instrumen Needs for Achievement

\begin{tabular}{lcccc}
\hline \multicolumn{1}{c}{ Indikator } & $\begin{array}{c}\text { Item } \\
\text { Pertanyaan }\end{array}$ & $\begin{array}{c}\text { Koefisien } \\
\text { Korelasi }(\mathrm{r})\end{array}$ & $\mathrm{r}$ tabel* & Keterangan \\
\hline $\begin{array}{l}\text { Menyukai tanggung } \\
\text { jawab pribadi dalam }\end{array}$ & $\mathrm{Q} 1$ & 0,318 & 0,2787 & Valid \\
$\begin{array}{l}\text { mengambil } \\
\text { keputusan }\end{array}$ & $\mathrm{Q} 7$ & 0,685 & 0,2787 & Valid \\
$\begin{array}{l}\text { Mau mengambil } \\
\text { resiko sesuai dengan }\end{array}$ & $\mathrm{Q} 3$ & 0,388 & 0,2787 & Valid \\
$\begin{array}{l}\text { kemampuannya } \\
\begin{array}{l}\text { Memiliki minat } \\
\text { untuk selalu belajar }\end{array}\end{array}$ & $\mathrm{Q} 2$ & 0,629 & 0,2787 & Valid \\
$\begin{array}{l}\text { dari keputusan yang } \\
\text { telah diambil }\end{array}$ & $\mathrm{Q} 4$ & 0,390 & 0,2787 & Valid \\
\hline
\end{tabular}

Sumber: Data Olahan (2013)

${ }^{*} \mathrm{r}$ tabel untuk $\mathrm{n}=50$, dengan degree of freedom $(\mathrm{df} \mathrm{N}-2)$ adalah 0,2787

Hasil Uji Validitas Keinginan Berwirausaha. Instrumen pengukuran Keinginan Berwirausaha yang akan digunakan dalam penelitian ini mengacu pada instrumen pengukuran yang digunakan oleh Indarti dan Rostiani (2008), yang mengelompokkan Keinginan Berwirausaha menjadi dua indikator yaitu tekad yang kuat untuk memilih karir menjadi seorang wirausaha dan keyakinan akan adanya peluang untuk berhasil menjadi seorang wirausaha. Pengukuran variabel Keinginan Berwirausaha dalam penelitian ini menggunakan lima item pernyataan untuk kedua indikator termasuk satu item pernyataan negatif, dimana kelima item pernyataan tersebut dilakukan terlebih dahulu pretest kepada 50 responden. Hasil dari pretest tersebut menghasilkan semua item pernyataan yang valid, sehingga dapat digunakan untuk mengukur variabel keinginan berwirausaha. Adapun hasil item pernyataan yang valid terlampir dalam Tabel dibawah ini.

Tabel 5. Hasil Pengujian Validitas Instrumen Keinginan Berwirausaha

\begin{tabular}{lcccc}
\hline \multicolumn{1}{c}{ Indikator } & $\begin{array}{c}\text { Item } \\
\text { Pertanyaan }\end{array}$ & $\begin{array}{c}\text { Koefisien } \\
\text { Korelasi (r) }\end{array}$ & r tabel* & Keterangan \\
\hline Tekad yang kuat & Q8 & 0,757 & 0,2787 & Valid \\
untuk memilih karir & Q10 & 0,470 & 0,2787 & Valid \\
$\begin{array}{l}\text { menjadi seorang } \\
\text { wirausaha }\end{array}$ & Q11 & 0,656 & 0,2787 & \\
$\begin{array}{l}\text { Keyakinan akan } \\
\text { adanya peluang }\end{array}$ & Q9 & 0,774 & 0,2787 & Valid \\
untuk berhasil & Q12 & 0,579 & 0,2787, & Valid \\
$\begin{array}{l}\text { menjadi seorang } \\
\text { wirausaha }\end{array}$ & & & & \\
\hline
\end{tabular}

Sumber: Data Olahan (2013)

${ }^{*} \mathrm{r}$ tabel untuk $\mathrm{n}=50$, dengan degree of freedom $(\mathrm{df} \mathrm{N}-2)$ adalah 0,2787

Hasil Uji Reliabilitas. Suatu instrumen penelitian dapat dikatakan reliabel apabila alpha lebih besar dari 0,6 (Ghozali, 2005). Adapun hasil pengujian reliabilitas pada intsrumen penelitian ini tertera pada tabel 6 . 
Tabel 6. Hasil Pengujian Reliabilitas

\begin{tabular}{ccc}
\hline \multicolumn{1}{c}{ Instrumen } & Alpha & Keterangan \\
\hline Needs for Achievement & 0,660 & Reliabel \\
Keinginan berwirausaha & 0,750 & Reliabel \\
\hline
\end{tabular}

Sumber: Data Olahan 2013

Dari hasil tabel di atas terlihat bahwa nilai alpha dari tiap instrumen penelitian lebih besar dari nilai yang ditetapkan, yaitu 0,6 sehingga dapat dinyatakan bahwa seluruh instrumen yang digunakan adalah reliabel. Dengan demikian alat ukur yang digunakan oleh peneliti akan memberikan jawaban yang konsisten dari waktu ke waktu.

Hasil Uji Asumsi Klasik. Normalitas. Untuk mengetahui apakah data berdistribusi normal atau tidak pada penelitian ini digunakan uji Kolmogorov-Smirnov menggunakan PASW SPSS 18. Model regresi dalam penelitian ini menggunakan data berdistribusi normal apabila Asymp. Sig. (2-tailed) lebih dari 0,05, namun apabila nilai nya kurang dari 0,05 maka data berdistribusi tidak normal.

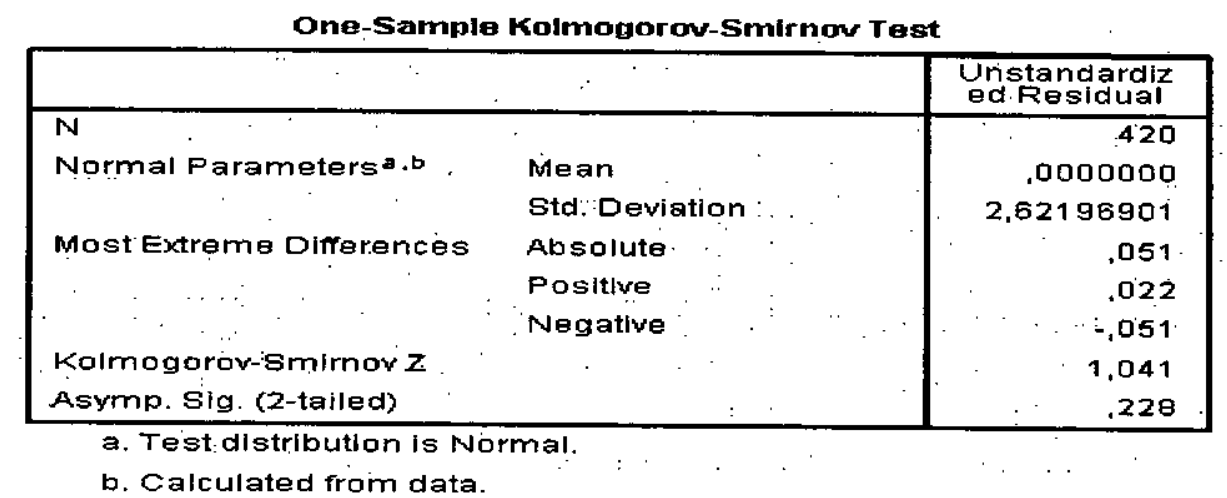

Gambar 2. Hasil Uji Normalitas

Sumber: data diolah

Berdasarkan gambar di atas, dapat disimpulkan bahwa data yang digunakan dalam penelitian ini berdistribusi normal. Hal ini tergambarkan dengan nilai Asymp.Sig. (2tailed) adalah sebesar 0,228 (lebih dari 0,05).

Multikolinieritas. Pengujian multikolinieritas di dalam penelitian ini dilakukan dengan menggunakan PASW SPSS 18. Model regresi dikatakan tidak terdapat multikolinieritas apabila mempunyai nilai VIF $<10$ dan mempunyai nilai Tolerance $>0,1$. Hasil pengujian multikolinieritas dapat dilihat pada tabel 5.6. adalah sebagai berikut:

Tabel 7. Analisis Multikolinearitas

\begin{tabular}{lccl}
\hline \multirow{2}{*}{ Variabel } & \multicolumn{2}{c}{ Collinearity Statistic } & \multirow{2}{*}{ Keterangan } \\
\cline { 2 - 3 } & Tolerance & VIF & \\
\cline { 1 - 3 } Needs for Achievement & 0.971 & 1,030 & Tidak ada Multikolinieritas \\
Jender & 0,922 & 1,085 & Tidak ada Multikolinieritas \\
Umur & 0,933 & 1,072 & Tidak ada Multikolinieritas \\
Pengalaman Kerja (PK) & 0,951 & 1,052 & Tidak ada Multikolinieritas \\
\hline Sumber: data olahan 2013 & & &
\end{tabular}

Sumber: data olahan 2013 
sedangkan nilai 0 menunjukkan mahasiswa yang tidak memiliki pengalaman bekerja. Berdasarkan persamaan regresi diatas, variabel dummy dalam penelitian ini memiliki nilai positif yaitu sebesar 0,157 . Hal ini diartikan bahwa terdapat perbedaan secara nyata antara mahasiswa yang memiliki pengalaman bekerja dengan mahasiswa yang tidak memiliki pengalaman bekerja, perbedaaan tersebut besarnya adalah 0,157 lebih tinggi untuk mahasiswa yang memiliki pengalaman bekerja.

Variabel Pengalaman Kerja $\left(D_{2}\right)$ dalam penelitian ini tidak memiliki pengaruh yang positif terhadap keinginan berwirausaha mahasiswa FE UNTAR, dibuktikan dengan tingkat signifikansi lebih dari $5 \%(\alpha)$ yaitu 0,608 . Hasil ini tidak mendukung hipotesis 4 yang menyatakan pengalaman kerja berpengaruh positif terhadap keinginan berwirausaha. Pengalaman bekerja yang telah mahasiswa FE UNTAR lakukan selama kuliah hanya dijadikan nilai tambah bagi mereka untuk memperoleh pekerjaan yang memberikan gaji yang lebih tinggi dari sebelumnya sebagai seorang karyawan disuatu perusahaan.

Koefisien Korelasi. Berdasarkan output pengolahan data yang tergambar pada tabel 9 diperoleh nilai koefisien korelasi sebesar 0,368 yang berarti hubungan antara variabel bebas dengan variabel terikat adalah sebesar 36,8\%. Ini berarti Needs for Achievement, Jender, Umur, dan Pengalaman Kerja mempunyai hubungan yang tinggi dengan keinginan berwirausaha mahasiswa FE UNTAR. Hal ini diartikan bahwa Needs for Achievement, Jender, Umur, dan Pengalaman Kerja memberi pengaruh yang signifikan terhadap keinginan berwirausaha mahasiwa FE UNTAR.

Koefisien Determinasi $\left(\mathbf{R}^{2}\right)$. Sementara itu koefisien determinasi sebesar 0,135 memiliki makna bahwa sebesar $13,5 \%$ perubahan-perubahan dalam variabel terikat berupa mahasiswa FE UNTAR dapat dijelaskan oleh perubahan-perubahan dalam faktor tematema Needs for Achievement, Jender, Umur, dan Pengalaman Kerja. Sedangkan selebihnya sebesar $86,5 \%$ dijelaskan oleh faktor-faktor lain diluar dari variabel tema-tema Needs for Achievement, Jender, Umur, dan Pengalaman Kerja seperti yang telah dijelaskan sebelumnya. Hal ini mengindikasikan bahwa Needs for Achievement, Jender, Umur, dan Pengalaman Kerja yang dimiliki mahasiswa FE UNTAR bukan menjadi faktor utama yang mempengaruhi keinginan berwirausaha.

\section{PENUTUP}

Kesimpulan. Hasil penelitian ini adalah: Pertama. Needs for achievement berpengaruh positif terhadap keinginan mahasiswa untuk berwirausaha. Hal ini dikarenakan kebutuhan akan prestasi bagi mahasiswa FE UNTAR sebagai salah satu karakteristik kepribadian mereka yang akan mendorong mereka untuk memiliki keinginan berwirausaha. Bagi mereka, kebutuhan akan prestasi mendorong kemampuan mereka dalam mengambil keputusan dalam berwirausaha. Kedua. Jender berpengaruh positif terhadap keinginan mahasiswa untuk berwirausaha. Alasannya karena perempuan cenderung kurang menyukai tantangan untuk membuka usaha baru dibandingkan kaum laki-laki. Sehingga dapat disimpulkan bahwa mahasiswa laki-laki memiliki keinginan yang lebih kuat dibandingkan dengan mahasiswa wanita. Ketiga. Umur tidak mempengaruhi keinginan mahasiswa untuk berwirausaha. Hal ini dikarenakan bahwa mahasiswa FE UNTAR tidak diberikan gambaran mengenai alternatif pilihan dalam berkarier selain menjadi karyawan perusahaan, oleh pengajar-pengajar yang ada. Sehingga mereka hanya berpatokan bahwa 
lulus dari kuliah mereka akan bekerja di sebuah perusahaan (menjadi karyawan). Alasan lainnya karena mahasiswa FE UNTAR belum memiliki keberanian untuk mengambil resiko menjadi seorang "enterprenuership". Keempat. Pengalaman kerja yang dimiliki mahasiswa FE UNTAR tidak mempengaruhi mahasiswa untuk berwirausaha. Alasannya karena bagi mereka memiliki pengalaman kerja sewaktu menyelesaikan studi kuliahnya hanya dijadikan nilai tambah untuk memperoleh pekerjaan yang dapat memberikan penghasilan yang lebih tinggi dibanding sebelumnya.

Saran. Berdasarkan kesimpulan dari hasil pengujian statistik di atas, maka saran-saran yang kiranya dapat bermanfaat bagi pihak yang hendak melakukan pengembangan penelitian selanjutnya adalah sebagai berikut: (1) Bagi akademisi, diharapkan dapat melanjutkan penelitian ini dengan menambah variabel lain yang dapat mempengaruhi mahasiswa memiliki keinginan berwirausaha.; (2) Bagi universitas khususnya pengajar, diharapkan dapat memupuk keinginan mahasiswa untuk mencoba memilih wirausaha sebagai pilihan karirnya setelah menyelesaikan studi kuliahnya.

Implikasi. Penelitian ini diharapkan dapat memberikan masukan bagi FE UNTAR, khususnya jurusan manajemen agar dapat mengadakan seminar kewirausahaan secara rutin, hal ini mampu meningkatkan minat mahasiswa untuk memilih "wirausaha" sebagai karir dalam hidupnya. Selain mengadakan seminar, FE UNTAR khususnya jurusan manajemen dapat menyelenggarakan workshop usaha kecil menengah (UKM) secara rutin yang diperuntukkan bagi mahasiswa yang memiliki talenta berwirausaha tetapi tidak memiliki wadah untuk menyalurkannya. Hal tersebut merupakan dorongan/motivasi bagi mahasiswa untuk menunjukkan kreativitasnya kepada publik dalam berwirausaha.

\section{DAFTAR RUJUKAN}

Agustina, Cynthia dan Lana Sularto, (2011). Intensi kewirausahaan mahasiswa: Studi perbandingan antara fakultas ekonomi dan fakultas ilmu komputer. Proceeding PESAT Universitas Gunadarma, Vol.4. Oktober. 63-69.

Chaniago, Junaidi. (2008). Regresi Atas Variabel Dummy. 22 September 2008. http:/junaidichaniago.wordpress.com/2008/09/22/regresi-atas-variabel-dummy/

Dalton, dan Holloway, (1989). Preliminary findings: entrepreneur study. Working paper, Brigham Young University

Ghozali, Imam, (2005). Aplikasi Analisis Multivariate dengan Program SPSS. Semarang: Badan Penerbit Universitas Diponegoro.

Hisrich, R. D., dan Peters, M. P., (2002). Entrepreneurship. 5th Edition, International Edition, New York McGraw-Hill.

Indarti, Nurul dan Rokhima Rostianai, (2008). Intensi kewirausahaan mahasiswa: Studi perbandingan antara Indonesia, Jepang, dan Norwegia. Jurnal Ekonomi dan Bisnis Indonesia, Vol.23, (4): 369-384

Kolvereid, L., (1996). Prediction of employment status choice intentions. Enterprenerurship Theory and Practice 21 (1): 47-57.

Kristiansen, S. B., Furuholt, dan F. Wahid, (2003). Internet cafe entrepreneurs: pioneers in information dissemination in Indonesia. The International Journal of Entrepreneurship and Innovation 4 (4): 251-263.

Lee, J., (1997). The motivation of women entrepreneurs in Singapore. International Journal of Entrepreneurial Behaviour and Research 3 (2): 93-110. 
Matthews, C. H. dan S. B. Moser. (1996). A longitudinal investigation of the impact of family background and gender on interest in small firm ownership. Journal of Small Business Management 34 (2): 29-43.

Mazzarol, T., T. Volery, N. Doss, dan V. Thein, (1999). Factors influencing small business start-ups. International Journal of Entrepreneurial Behaviour and Research 5 (2): 48-63

McClelland, D., (1961). The Achieving Society. Princeton. New Jersey: Nostrand.

McClelland, D., (1971). The Achievement Motive in Economic Growth, in: P. Kilby (ed.) Entrepreneurship and Economic Development, New York The Free Press, 109-123.

Remenyi, D., B. Williams, A. Money, dan E. Swartz, (2000). Doing Research in Business and Management: An Introduction to Process and Method. Sage Publication, London

Reynolds, P.D., dan M. Hay, W.D. Bygrave, S. M. Camp, dan E. Aution, (2000). Global entrepreneurship monitor: executive report. A Research Report from Babson College, Kauffman Center for Entrepreneurial Leadership, and London Business School.

Scapinello, K.F., (1989). Enhancing differences in the achievement attributions of high and low motivation groups. Journal of Social and Psychology 129 (3): 357-363.

Scott, M. dan D. Twomey, (1988). The longterm supply of entrepreneurs: students career aspirations in relation to entrepreneurship. Journal of Small Business Management 26 (4): 5-13.

Schiller, B.R., dan P.E. Crewson, (1997). Enterpreneurial origins: a longitudinal inquiry. Economic inquiry 35 (3): 523-531.

Sengupta, S.K. dan S.K. Debnath, (1994). Needs for achievement and entrepreneurial success: a study of entrepreneurs in two rural industries in West Bengal. The journal of Entrepreneurship 3 (2): 191-204.

Sinha, T. N., (1996). Human factors in entrepreneurship effectiveness. Journal of Entrepreneurship 5 (1): 23-29.

Sugiyono, (2008). Metode Penelitian Bisnis. Alfabeta, Bandung

www. bps.go.id

www.dikti.go.id

Winarno, Wing Wahyu. (2009). Analisis Ekonomietrika dan Statistika Dengan Eviews. Yogyakarta: Unit Penerbit dan Percetakan Sekolah Tinggi Ilmu Manajeme YKPN. 